\title{
Evaluation of Water Balance in a Mountainous Upland Catchment Using SEBAL Approach
}

\author{
Mohammad Taghi Dastorani • \\ Samaneh Poormohammadi
}

Received: 9 March 2011 / Accepted: 1 February 2012 /

Published online: 19 February 2012

(C) Springer Science+Business Media B.V. 2012

\begin{abstract}
Scarcity of water is now the biggest threat in many parts of the world, specially in arid and semi arid regions. Establishing balance between water resources and the demands in a catchment scale basis could be one of the most important strategies to overcome this problem. In this regard, determination and analysis of water balance components (inputs and outputs) would be necessary. This study has focused on estimation of water balance components in arid-mountainous catchment of Manshad in Yazd province of Iran, during the year 2006-2007 using remote sensing and GIS techniques. To estimate actual evapotranspiration $\left(\mathrm{ET}_{\mathrm{a}}\right)$ of the catchment, time series of MODIS images were obtained and used via Surface Energy Balance Algorithm for Land (SEBAL) approach. Measured precipitation $(\mathrm{P})$ and runoff $(\mathrm{R})$ data of the catchment were also used to calculate water balance equation components. Results indicated that a large volume of catchment water (about 70\%) is wasted through evapotranspiration, while the rainfall is not enough to compensate this volume of water during the year. It seems that the negative (descending) trend has become dominant to the water budget of the area and gradually moves to harsh conditions of water shortage in future decades. Therefore, some actions would be necessary to overcome the problem. Water conservation strategies, improvement of water use efficiency, and control on agricultural field expansions are some solutions that could be advised for the studied catchment.
\end{abstract}

Keywords Water scarcity $\cdot$ Water balance $\cdot \mathrm{SEBAL} \cdot$ Evapotranspiration $\cdot$ Manshad $\cdot$ Yazd

\section{Introduction}

Limited water of the Earth that keeps going around and around (water cycle) is the main essential component of the global hydrological cycle (Dingman 2002). This cycle is made up of different parts like evaporation (and transpiration), condensation, precipitation and collection, in which water has a key role in all the parts (Smith and Stopp 1978). In smaller scales like watershed or catchment, water also affects other catchment resources such as soil,

M. T. Dastorani $(\bowtie) \cdot$ S. Poormohammadi

Faculty of Natural Resources, Yazd University, Yazd, Iran

e-mail: mdastorani@yazduni.ac.ir 
weather, agriculture, natural vegetation, industry and livestock. Unfortunately, water shortage is now turned to be the biggest threat for people in many parts of the World. The main cause of this problem is long-term imbalances between available water resources and water demands of different sectors in addition to the effects of climate change phenomena. Therefore the main solution to overcome the problem is establishing the balance between available water resources and the demands in a catchment scale basis. Estimation of water balance component would help to understand and manage the catchment's water properly. It also addresses current and future water use scenarios (Senay et al. 2007). A water balance model forms an important tool for analysis of hydrological behavior of a catchment. Also it is used to assess the system sensitivity to natural or imposed impacts such as climate and land use changes (Rientjes 2007). Therefore, during last few decades water balance models have been developed and used at various time scales (e.g. hourly, daily, monthly and yearly) and to varying degrees of complexity. Monthly water balance models were first developed in the 1940s (Xu and Singh 1998). For instance Xu (1999) used a conceptual 6-parameter water balance model which was applied to 26 seasonally snow covered catchments in central Sweden. The results showed that the model can be satisfactorily applied to ungauged basins in the study region. Chen et al. (2005) used a water budget model for the Yun-Lin Plain in Taiwan. In this model, infiltration was described by Philip's solution in conjunction with the time compression approximation method during rainfall, and the soil profile drainage was determined by evapotranspiration and recharge. Cumulative infiltration, runoff, evapotranspiration and recharge were estimated with different climate conditions and different soil hydraulic properties during simulating period. Results showed that the amount of annual recharge was affected by the amount of annual rainfall and soil properties. Tang et al. (2007) used a conceptual water balance methodology for evaluating groundwater movement among riverway, irrigation ditches, irrigation area and non-irrigation area, based on the recorded water diversion. Results showed that both irrigation area and non-irrigation area are supported by the water from river way in hyper-arid environments. Nearly half of the water in the non-irrigation area comes from the irrigation area in the form of groundwater. Therefore, tight water connection between irrigation area and non-irrigation area suggests that natural ecosystem needs to be considered in agricultural management in arid environment. Manghi et al. (2009) estimated regional groundwater recharge using a hydrological balance method. In this method, ARCGIS 9.0 Geostatistical and Spatial Analyst applications were used for interpolating/extrapolating and creating grids for specific yield, bedrock elevation, and raw groundwater data. In order to avoid difficulties in estimating these variables, the differences between total applied water and water losses, other than via the subsurface to adjacent basins, were lumped into a single term- groundwater recharge. Chami et al. (2009) investigated the seawater intrusion to determine the regional water balance of a coast district in Lebanon for evaluation of economic value of water for agricultural use. The results showed that the annual regional water balance is positive but the coastal part of the region is slightly contaminated by seawater intrusion due to the excess of pumping from the aquifer. He et al. (2009) evaluated the land use impacts on regional scale urban water balance in Dogo Plain of the Seto Inland Sea of Japan. In this research a distributed four-black three-layer water balance model was used to analyze the groundwater table fluctuation with response to the change of paddy field area. Abdulla et al. (2009) evaluated the impact of potential climate change on the water balance at a semi-arid watershed in Jordan. Results showed that climate warming can dramatically impact runoff and groundwater recharge. Jasrotia et al. (2009) evaluated water balance for rain water harvesting in India. In this study Thornthwaite and Mather (TM) models used with the help of remote sensing and GIS to find out the moisture deficit and moisture surplus for an entire watershed, and the methodology was evaluated 
very useful. Höllermann et al. (2010) used WEAP (Water Evaluation and Planning System) for evaluation of water balance and future water availability in Benin. The results showed that the pressure on Benin's water resources will increase leading to greater competition for surface water in the future. Fujihara et al. (2011) used the simple semi-distributed water balance model for hydrologic analysis of rainfed rice areas in Thailand. The results were evaluated satisfactory when the water movement between different land uses was considered. Setegn et al. (2011) studied the water balance for Lake Alemaya in Ethiopia under presumed scenarios in order to study the possible trends and fluctuations of the lake water level. Elhag et al. (2011) used the SEB (Surface Energy Balance) water balance model for estimation of daily evapotranspiration over the Nile delta. The results showed good applicability and accuracy in the estimation of daily evapotranspiration over agricultural areas.

A simple water balance model for a catchment consists of $\mathrm{P}$ as precipitation, ET as evapotranspiration, $\mathrm{R}$ as runoff and $\Delta S$ as the storage variations. Precipitation is generally measured in rain gauge stations and fully depends on climate and topography, and the runoff is usually measured in flow gauging stations. Generation of runoff in a catchment mainly depends on rainfall amount, intensity and form and also land surface features such as vegetation, slope, soil type and etc. (Dankers 2001). Several hydrological models have been developed for modeling of rainfall-runoff process. These models are capable to simulate ungauged catchments through parameter transfer with better accuracy using the available hydrometeorogical data (Nhedzi 2008). Changes in soil water storage $(\Delta S)$ are measured through continuous soil sampling and generation of a soil water budget between initial and final time interval. Groundwater inflow and outflow are mostly assumed to be equal except for the cases where required data are available. For estimation of ET, two main procedures exist; first one calculates the ET as the residual of water balance equation, and the second one estimates the ET via existing equations and methods and puts it into the equation to calculate $\Delta S$. In this regard, Geographic Information System (GIS) as a computerized tool would help for advanced analysis and modeling of the water balance components both in time and space. Also Remote Sensing (RS) technique provides a reliable facility to measure, monitor, forecast and model the spatial and temporal variations of water balance components (Heafner and Schumann 1992). Evapotranspiration is one of these parameters that could be estimated via RS capabilities. One of the advantages of the mentioned procedure is production of a large amount of spatial and temporal information about ET as well as other required parameters, with relatively low cost and time consumption. In this procedure, the energy balance equation (Eq. 1) is solved for calculation of latent heat flux (LH) that is equal to the energy consumed by evapotranspiration.

$$
\mathrm{R}_{\mathrm{n}}+\mathrm{G}+\mathrm{H}+\mathrm{LH}=0
$$

Where LH is actual evapotranspiration of desired surface. $\mathrm{R}_{\mathrm{n}}$ is existing net radiation in the surface, $\mathrm{G}$ is ground heat flux (the energy stored in the soil and vegetation), and $\mathrm{H}$ is the sensible heat flux used to heat the air. Determination of energy balance equation terms via RS approach requires also high quality data sets such as instantaneous meteorological data (wind speed and temperature) and some field investigations like vegetation features (height) and land use information. Several studies have been carried out to estimate ET using RS technique. Allen et al. (2005) described the steps for estimation of actual ET via surface energy balance method that employs anchor pixels (hot and cold pixels) approach presented by Bastiaanssen et al. (2002).

It needs to be mentioned that as found in the literatures, above mentioned method has been so far mostly used to calculate water balance component in agricultural fields. However, the present research was designed to evaluate the application of this method in 
catchment scale basis where mostly covered with natural landscape (Rock and Poor rangelands) in a dry environment. In other word, the main objective of the present study is to estimate water balance components of an arid-mountainous catchment in Yazd province of Iran. In this study RS technique is used to estimate actual evapotranspiration by SEBAL (Surface Energy Balance Algorithm for Land) approach, and also GIS capabilities to generate other water balance components quantity.

\section{Materials and Methods}

\subsection{Study Area}

The study area for this research is Manshad catchment, a typical intermountain region in Yazd province of Iran. It is located in Shirkooh Mountains of Yazd in central Iran with $61.37 \mathrm{~km}^{2}$ drainage area. This catchment lies between $31^{\circ} 29^{\prime} 08^{\prime \prime}$ to $31^{\circ} 36^{\prime} 24^{\prime \prime}$ north latitude and $54^{\circ} 09^{\prime} 56^{\prime \prime}$ to $54^{\circ} 16^{\prime} 37^{\prime \prime}$ east longitude. The topography of the study area is generally rugged except in the broad valley floor in the central part of the watershed. It ranges from a broad, flat alluvial valley to steep, rugged mountain slopes. The weighted average slope of the catchment is about $75 \%\left(32^{\circ}\right)$. The elevation ranges over $1,730 \mathrm{~m}$ through the catchment, resulting in a strong climatic gradient. The lowest elevation on the watershed is $1,788 \mathrm{~m}$ above the sea level at the outlet and the highest elevation is $3,518 \mathrm{~m}$ at the southern boundary of the catchment.

Based on the statistics, the climate condition of the catchment is semi-arid and cold, where monthly mean temperature is 0.8 and $24^{\circ} \mathrm{C}$ respectively in February and September, with annual average of about $11^{\circ} \mathrm{C}$. The climate of the Manshad catchment and more localised distribution of soils and vegetation are largely controlled by the elevation and local topography. The catchment's main seasonal stream flow is generated at the highest elevations in the south and south west where deep and late lying snow packs are the main source for water. Local slope and aspect strongly influence the hydrology of the catchment by controlling the incoming solar radiation and snow deposition patterns.

The Manshad catchment represents typical arid and semiarid climate conditions where climate elements vary highly from part to part. For example in higher elevation parts of the catchment mean annual precipitation is over four times more than lower elevation parts. Annual Precipitation varies considerably from low elevations to south and south west high elevation areas. It is about $190 \mathrm{~mm}$ at the northern and north east low elevation parts near the outlet while in southern part of the catchment the annual precipitation is over $780 \mathrm{~mm}$ of which more than $60 \%$ occurs as snowfall. In the study area water from snowmelt is very important, as it is the main source of soil moisture and stream flow during spring and summer. As expected, the maximum and minimum air temperature varies between different parts because of the variation of elevation. Soil and vegetation in the catchment are also influenced mainly by topographical conditions. In different parts of the catchment soils with variable characteristics derived from different geological formations such as granitic and limestone are seen. Geologically, most of the region belongs to Shirkuh intrusive rocks (post middle Jurassic), with granite and granodiorite rocks at upper part of the catchment, and older terraces with gravel fans (alluvium) in right side, and also grey limestone (Taft formation) in down part of the catchment. Soils range from shallow, desertic soils at the steep parts to deep organic soils at the valley sides, which are mostly dominated by orchards. Plant communities in the catchment are also strongly influenced by elevation. 
Most parts of the catchment are used as pasture for livestock grazing, although there are some irrigated fields at the lower elevations beside the main stream. About 530 ha. are dense orchards or agricultural farm lands and the remaining 5,607 ha. of the catchment area are mostly covered with rock lands and poor rangelands. Agricultural products in the region are mostly walnut, apricot and mulberry mix orchards with alfalfa, wheat and barely intercropping fields. The sources of applied water are mainly springs and wells during the year, and also the seasonal surface water flowing in the main stream during the winter and spring seasons. Figure 1 illustrates the location of study area of this research.

From water balance point of view, mountainous catchments are different from catchments at the hilly and plain areas. Due to specific local topography and rugged mountain slopes in mountainous catchments, the rate of runoff generation is higher and also generated run off drains faster, forming relatively higher discharges. In addition, due to rugged topography the most parts of the catchments are covered by rocks, rangelands and forests and generally the agricultural lands are limited. This means that the vegetation cover and species are quite variable in the catchment, causing variation in evapotranspiration rate from part to part inside the catchment. The second difference between mountainous catchments and the catchments in hilly and plain areas is the groundwater as an important component of water balance. In most of the catchments located in plain areas, deep percolation occurs and extended aquifers exist. However, in most of the mountainous catchments infiltrated water moves downward as subsurface flow recharging springs and the main stream in lower parts of the catchments. In Manshad catchment, due to the rugged topography less than $10 \%$ of the catchment area belongs to agricultural lands located mostly beside the main stream. In addition, in this catchment due to lower depth of sediment deposition, no aquifer exist, and the filtrated water discharges to the local springs or the main stream which is measured at the outlet of the catchment.

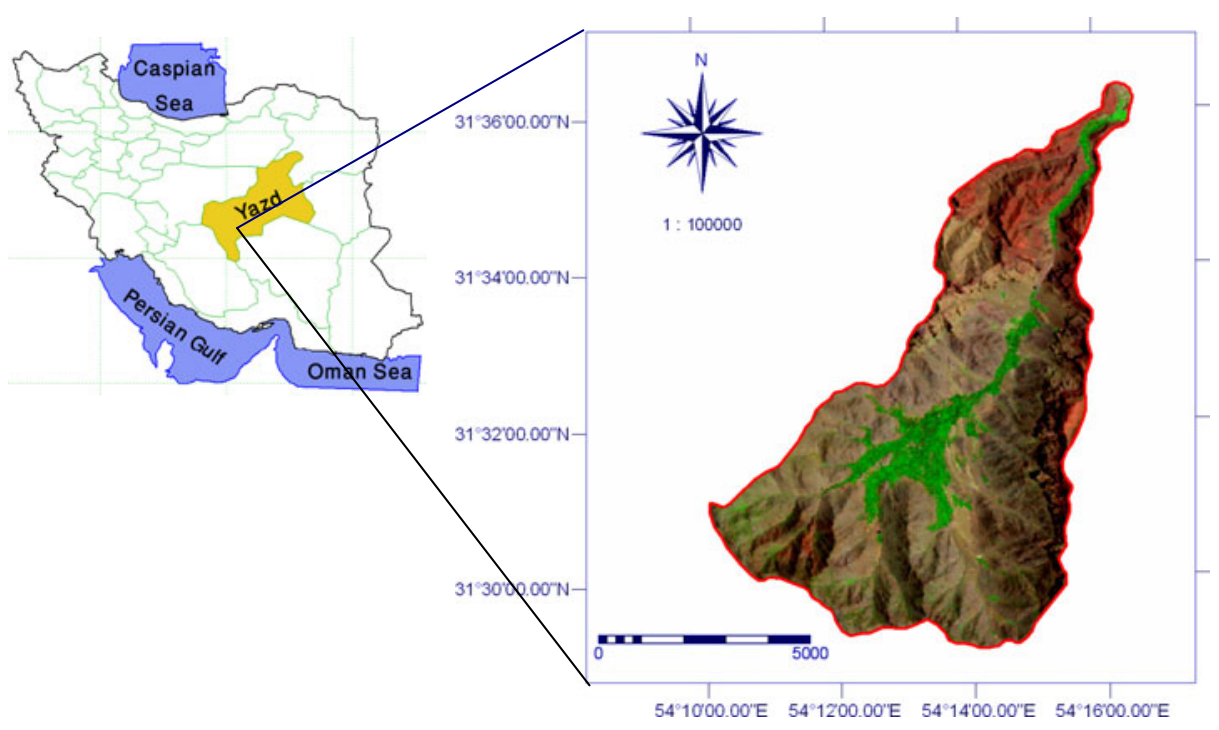

Fig. 1 Geographical location of Manshad catchment, located in Yazd province, central part of Iran 


\subsection{Water Balance Equation}

The common form of water balance equation in a given soil profile would be as follow:

$$
P+I+C-E T-R-D P=\Delta S
$$

Where, $\mathrm{P}$ is precipitation, $\mathrm{I}$ is irrigation, $\mathrm{C}$ is capillary rise of water from soil water storages to the root zone soil profile, ET is evapotranspiration of natural vegetations, orchards and agricultural fields and also evaporation from lakes, canals and rivers, $\mathrm{R}$ is runoff leaving the catchment, DP is deep percolation (infiltrated water from surface to deeper soil horizons) and finally $\Delta S$ is the changes in water storage of the soil profile during the studied period. In a catchment scale, some parts of the equation can be ignored. The main inflow components to a catchment are precipitation, surface (streams) and subsurface water (groundwater) entered to the catchment. Therefore, irrigation water could be eliminated from the input parameters, if main sources of irrigation water are surface or groundwater which have been previously supplied and recharged by rainfall. Also soil related parameters (like DP, $\mathrm{C}$ and $\Delta S$ ) are sometimes in relation with the water consumed by the plants and green vegetation in the surface (ET). Manshad is a relatively small steep mountainous catchment that the main source of water which is used for irrigation is subsurface water extracted from shallow wells, springs and Qanats (gravimetric conveyance of subsurface water to the surface) in the catchment that are all considerably affected by annual precipitation. There is no groundwater resources in the catchment as the catchment is completely mountainous area with high ground slope, and impermeable parent materials near to the surface. Since boundaries of the catchment are quaternary mountain ranges with sharp slopes in the top border line, it seems that the underground recharges from neighboring catchments would be negligible. The water inflow into the catchment is therefore considered to be only from precipitation occurring inside the catchment $(\mathrm{P})$ while water leaving the catchment includes runoff $(\mathrm{R})$ and actual evapotranspiration $\left(\mathrm{ET}_{\mathrm{a}}\right)$. Differences between input and output parameters represents the changes in soil moisture storage $(\Delta S)$. Therefore, the following simple form of water balance equation was used in the study:

$$
P=E T_{a}+R+\Delta S
$$

Figure 2 represents the steps for determination of water balance components in the study area. As shown in the figure, different sources of data were used to model and evaluate water balance components in this study.

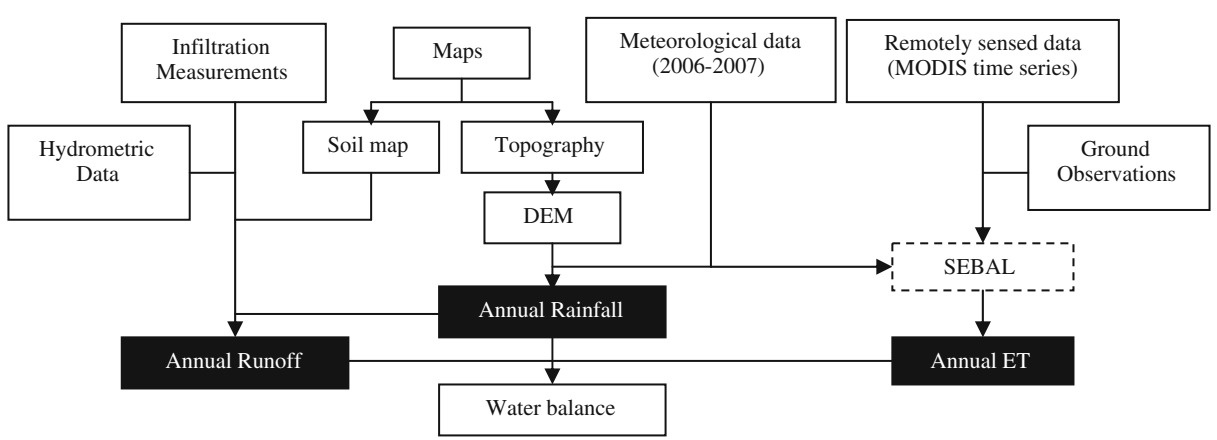

Fig. 2 Flowchart for determination of water balance components in Manshad catchment, Yazd province, Iran 


\subsection{Annual Precipitation and Runoff}

For determination of annual precipitation, collected data of Manshad meteorological station as well as the surrounding rain gauge measurements were used and analyzed to generate a regression-based equation representing rainfall in relation to the elevation of the stations. Using Digital Elevation Model (DEM) map and applying the related regression equation, spatial distribution map of rainfall was generated for the catchment.

In addition, the runoff data of studied period were calculated from the Manshad hydrometric station (flow gauging station), located at the outlet of the catchment.

\subsection{Annual $\mathrm{ET}_{\mathrm{a}}$}

As a main part of the study, the Surface Energy Balance Algorithm for Land (SEBAL) approach was used for determination of the annual actual ET of the catchment. This algorithm uses digital satellite images that record thermal infrared radiation in addition to visible and near infrared radiation, and computes ET on a pixel basis for the instantaneous time of the satellite overpass. This algorithm predicts ET from the residual amount of energy in the form of latent heat flux (LE) which is equal to Rn-G-H, where Rn is above ground surface net radiation, $\mathrm{H}$ is sensible heat flux and $\mathrm{G}$ is the ground heat flux. Details about the SEBAL procedure and steps for running the algorithm can be found in Bastiaanssen et al. (1998a, b) and also Bastiaanssen (2000). For the purpose of having actual ET at the study site, SEBAL algorithm was implemented using utilized time series of RS data and also ancillary climatic parameters as well as crop and land characteristics. The RS data included 15 cloud free images of MODIS level 1B as shown in Table 1. Additionally, an image of Landsat $\mathrm{ETM}^{+}$(10 Jul. 2002) was also used for preliminary interpretation of the region and selection of the critical pixels (pixels with extreme values) required in SEBAL procedure, because of its higher spatial resolution ( $30 \mathrm{~m}$ in comparison to the MODIS products which is $250 \mathrm{~m})$.

For calculation of 24-hr actual ET from instantaneous ET of SEBAL, the constant daily values of evaporative fraction (EF) were calculated for each day (Bastiaanssen et al. 1998b):

$$
E F=\frac{L E}{L E+H}=\frac{L E}{R_{n}-G}
$$

Then, EF was multiplied by the instantaneous ET maps and therefore, 24- hr ET were generated for the satellite overpass days, separately. To have annual actual ET map, daily

Table 1 The characteristics of satellite images used in the study

\begin{tabular}{|c|c|c|c|c|c|c|c|}
\hline Image No. & Date & Type & \# bands & Image No. & Date & Type & \# bands \\
\hline 1 & 23-Sep-06 & MODIS/Terra & $1,2,31,32$ & 9 & 03-May-07 & MODIS/Terra & $1,2,31,32$ \\
\hline 2 & 02-Oct-06 & “ & “ & 10 & 28-Jun-07 & “ & “ \\
\hline 3 & 27-Oct-06 & “ & “ & 11 & 01-Jul-07 & “ & “ \\
\hline 4 & 23-Nov-06 & “ & “ & 12 & 17-Jul-07 & “ & “ \\
\hline 5 & 30-Dec-06 & “ & “ & 13 & 05-Aug-07 & “ & “ \\
\hline 6 & 15-Jan-07 & “ & “ & 14 & 20-Aug-07 & “ & “ \\
\hline 7 & 27-Jan-07 & “ & “ & 15 & 05-Sep-07 & “ & “ \\
\hline 8 & 28-Feb-07 & “ & “ & 16 & 10-Jul-02 & Landast/ETM ${ }^{+}$ & $7,4,2$ \\
\hline
\end{tabular}


reference $\mathrm{ET}$ or $\mathrm{ET}_{\mathrm{o}}$ (a climatic parameter expressing the evaporation power of the atmosphere) were calculated via FAO-penman-montieth equation (Allen et al. 1998). Using Eq. (5), the actual ET of days between images interval $\left(\mathrm{ET}_{\text {period }}\right)$ were estimated, and finally annual actual ET (2006-2007) was calculated (Eq. 6).

$$
\begin{aligned}
E T_{\text {period }_{i}} & =\frac{E T_{a i}}{E T_{o i}} \sum_{j=k}^{l} E T_{o j} \\
E T_{\text {annual }} & =\sum E T_{\text {period }_{i}}
\end{aligned}
$$

Where $\mathrm{i}$ is the period number (equal to the image number) and $\mathrm{j}$ is day number (varies between $\mathrm{k}$ to 1 ).

\subsection{Validation Procedure}

Estimated values for actual evapotranspiration were compared to the maximum possible values for ET calculated from rainfall-run off data analysis. Based on the water balance concepts, maximum possible value for ET $\left(\mathrm{ET}_{\max }\right)$ occurs when the whole precipitation leaves the catchment through runoff and evapotranspiration. Therefore, the maximum value for ET would be as follows:

$$
E T_{\max }=P-R
$$

In this case, deep percolation and also changes of soil water storage would be negligible. Also minimum possible value for ET $\left(\mathrm{ET}_{\min }\right)$ occurs when the soil water storage $(\Delta S)$ would be at its maximum rates. Therefore $\mathrm{ET}_{\min }$ can be estimated as follows:

$$
E T_{\min }=P-R-\Delta S
$$

In this case, a large portion of entered water would be stored or percolated through the soil profile. For determination of soil water storage $(\Delta S)$, soil infiltration rate was measured via installation of double ring in each hydrologic soil group. Navigation and selection of suitable sites for double ring installation and measurement was performed using the GPS utilities as well as the satellite false color composite and also the hydrologic soil group maps.

Using the instantaneous records for all occurred rainfall events in the studied time period and also measured permeability rates of the soils, volume of infiltrated water were separately estimated for each rainfall event. Then the total amount of infiltrated water for the studied time period was calculated.

\section{Results and Discussion}

Figure 3 shows temporal distribution of daily reference ET and also precipitation during 2006-2007 cropping season. As shown in the figure, reference ET is dominant for most of the days, except for few days between December and March. This indicates that the area is essentially arid and therefore, a negative trend of water budget would be anticipated in the region. On the other hand, the recharge resources of water is limited and therefore, the ground water resources are at risk, due to high evaporation demand of the atmosphere as well as increasing local demand for agricultural, industrial and domestic uses. 


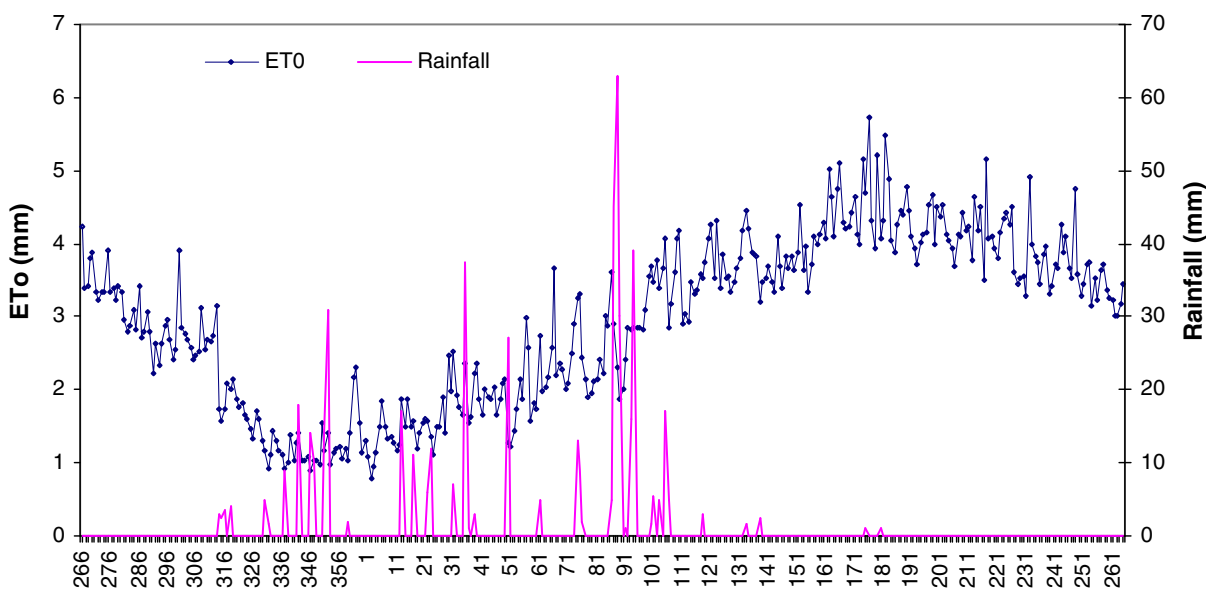

Day Of Year

Fig. 3 Temporal variation of rainfall and adjusted daily reference evapotranspiration on Manshad catchment during 2006-2007

Based on the annual rainfall map, the amount of precipitation varies between 230 and $900 \mathrm{~mm}$, in different parts of the catchment with an average of $560 \mathrm{~mm}$ during the year 2006-2007. Calculations for of soil infiltration indicated that about $125 \mathrm{~mm}$ of water can be infiltrated through the soil and stored in the deeper horizons, but accessible for evapotranspiration by trees and vegetations. Also the average calculated runoff depth was $109 \mathrm{~mm}$ in the studied year. A simple water balance equation indicates that evapotranspiration of green vegetated surfaces is the main way of wasting the water in the catchment. Figure 4 shows annual ET of the area estimated via SEBAL procedure.

As mentioned, Fig. 4 shows spatial distribution of evapotranspiration of the catchment in the studied year. Compared with different surface features and land uses (Fig. 1) it can be seen that the lowest evapotranspiration values belong to rugged mountainous areas with bare rocky or sparse vegetated surfaces. Regions with dense vegetation (agricultural fields and orchards) as well as water bodies such as main streams near the outlet have the highest ET values. As described before, main agricultural activities of the region is limited to orchards and also intercropping of some grains and cereals. Based on FAO-penman-montieth calculation procedure (Allen et al. 1998), seasonal evapotranspiration of almond, mulberry and walnut (as the main trees of the region) are respectively about 880, 980 and 1,083 $\mathrm{mm}$. Also wheat, alfalfa and vegetables have a seasonal evapotranspiration of about 730, 988, and $477 \mathrm{~mm}$, respectively. Generated ET map (Fig. 4) indicates that the values for ET of orchards and agricultural fields are in accordance with the above mentioned crop evapotranspirations. However, based on the map, the annual actual ET varied between 27 and 1,174 $\mathrm{mm}$ in different parts of the catchment; with average value of $540 \mathrm{~mm}$ for the whole catchment area. Validation procedure indicates that the values of actual ET must be estimated between 326 and $451 \mathrm{~mm}$, as two possible extreme values for ET. However, the generated ET map shows an overestimation error of about $17 \%$.

Finally, water balance components of the region have been calculated and illustrated in Fig. 5. This figure shows the portion of each component in supplying or consuming of water in Manshad catchment. As shown, a large volume of catchment water is wasted through evapotranspiration, and the annual rainfall is not enough to compensate this volume of water, unless other water balance components such as runoff or soil moisture storage move down near to zero. 


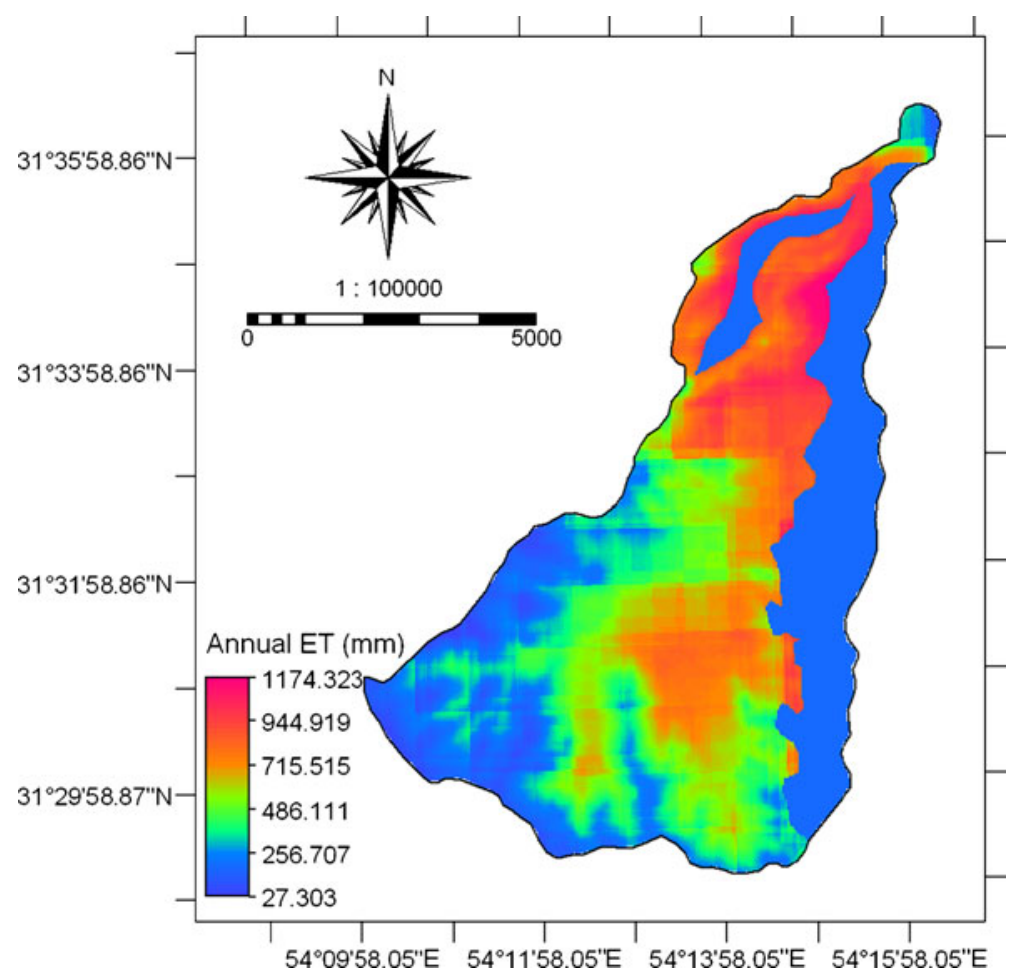

Fig. 4 Annual actual ET map of Manshad catchment during 2006-2007 Via SEBAL algorithm

Based on the water demand for evapotranspiration in different vegetation covers, and also annual recharge of the region through precipitation, it seems that the trend for water budget

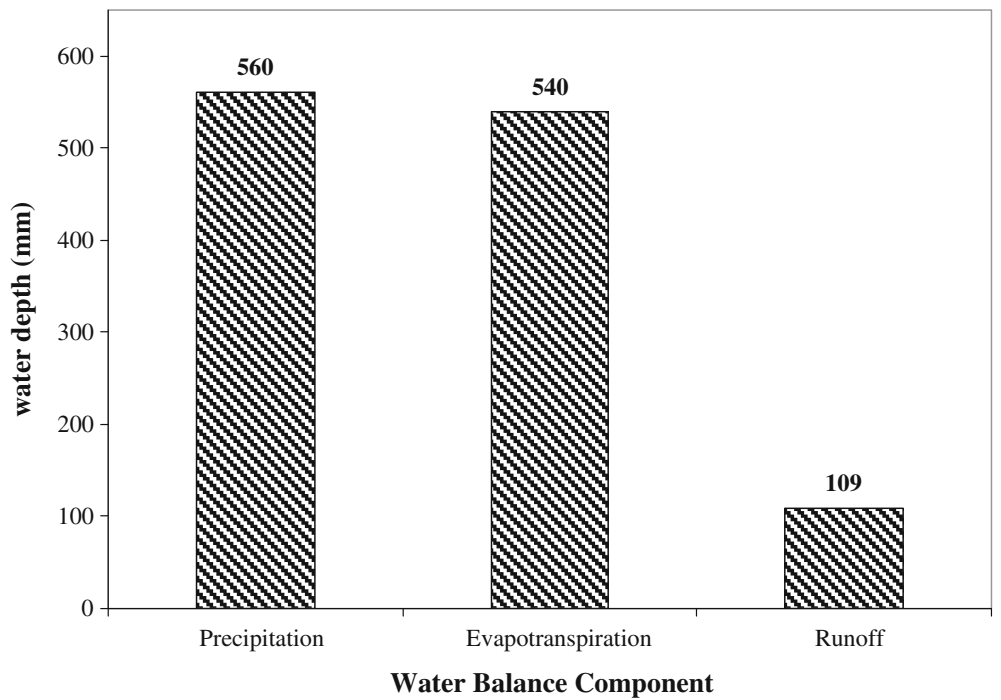

Fig. 5 Estimated values of different water balance components in Manshad catchment during 2006-2007 
in the region is negative and moving gradually to harsh conditions of water shortage in future decades. It seems that some actions would be necessary to overcome the problem. Water conservation strategies and improvement of water use efficiency with no agricultural field expansions are some solutions that could be advised (with special consideration of probable downstream effects) for the studied catchment.

\section{Conclusions}

Determination of water balance components in a catchment scale usually deals with some uncertainties due to variation of the related variables in time and space. These variations arise from nature of the hydrological data and also variations in topography, soil, vegetation cover and etc. For instance, the average annual precipitation of the studied region for year 2006-2007 is $560 \mathrm{~mm}$ (as a water balance component), while it varies between 230 and $900 \mathrm{~mm}$, spatially. Unfortunately, the mean value does not show variations and distributions of the rainfall. For example, inside the same catchment one would like to focus on areas with $400 \mathrm{~mm}$ and another one on areas with $700 \mathrm{~mm}$ of precipitation, while both of them discuss about the precipitation of Manshad catchment. For the first case, the water balance trend would be negative, while for the second one it would be positive. Also in mountain areas the rate of variation in runoff is considerable due to sever variation of topography, ground slop, soil, geology and etc. it means that in this type of catchments the spatial pattern of runoff is complex. In addition, considerable temporal variation of the affective factors such as precipitation (specially in dry land catchment) causes more uncertainty in calculation of water balance components. For example, water balance analysis for Manshad catchment in two different years may lead to completely different results due to considerable variation of the annual precipitation amount from 1 year to another (in some years it is three times more than some other years in a record period of 30 years). Therefore, uncertainties in water balance components are being the major problem to obtain reliable results. Due to the uncertainties associated with water balance modeling specially in a catchment scale basis, classic water balance models have difficulties in reliable estimation of evapotranspiration. As mentioned earlier, in classic methods, for estimation of this parameter two approaches are used: ET is calculated as the residual of water balance equation (after estimation of other parameters), or it is calculated as a portion of potential or reference evapotranspiration calculated using some empirical formulae and applying the crop coefficient $(\mathrm{Kc})$. In both methods uncertainties are higher causing considerable error. In agricultural fields where homogeneity of vegetation type and cover as well as topography condition are high, the classical methods can be used with lower errors. However for cathcments and specially mountainous catchments where the variation of topography as well as vegetation cover and type (so the $\mathrm{Kc}$ ), and meteorological parameters are considerable using classical methods may lead to considerable errors in estimation of ET. In contrast, in approach used in this research (SEBAL) the actual ET is estimated using the satellite images for different parts of the catchment based on real condition of the vegetation cover and meteorological parameters of each part so would be more reliable and precise for the catchments where the parameters are considerably variable from place to place inside the catchment.

Acknowledgement This research describes work undertaken as MSc thesis submitted to Yazd University of Iran. Special thanks go to Eng. M.H. Rahimian, Eng. M. H. Mokhtari and Dr. S. A. M. Cheraghi for their great supports, helps and encouragements. 


\section{References}

Abdulla F, Eshtawi T, Assaf H (2009) Assessment of the impact of potential climate changeon the water balance of a semi-arid watershed. Water Resour Manag 23:2051-2068

Allen R, Pereira LS, Raes D, Smith M, (1998) Crop evapotranspiration: guidelines for computing crop requirements. FAO Irrigation and Drainage Paper No. 56, Rome: Italy

Allen RG, Tasumi M, Morse AT, Trezza R (2005) A landsat-based energy balance and evapotranspiration model in Western US water rights regulation and planning. J Irrigat Drain Syst 19(3-4):251-268(18)

Bastiaanssen WGM (2000) SEBAL-based sensible and latent heat fluxes in the irrigated Gediz Basin, Turkey. J Hydrol 229:87-100

Bastiaanssen WGM, Menenti M, Feddes RA, Holtslag AAM (1998a) A remote sensing surface energy balance algorithm for land (SEBAL). J Hydrol 212-213

Bastiaanssen WGM, Menenti M, Feddes RA, Holtslag AAM (1998b) A remote sensing surface energy balance algorithm for land (SEBAL): 1) Formulation. J Hydrol 212(213):213-229

Bastiaanssen WGM, Ahmad MD, Chemin Y (2002) Satellite surveillance of evaporative depletion across the Indus Basin. Water Resour Res 38(12):1273

Chami DE, Moujabber ME, Scardigno A (2009) Regional water balance and economic assessmentas tools for water management in Coastal Lebanon. Water Resour Manag 23:2361-2378

Chen J-F, Lee C-H, Yeh T-C, Yu J-L (2005) A water budget model for the Yun-Lin Plain, Taiwan. Water Resour Manag 19:483-504

Dankers R (2001) A large scale water balance model of the Tana river basin, ICG report 01/2, Utrecht, Center for Geological Research, Faculty of Geographical Sciences, University of Utrecht

Dingman SL (2002) Physical hydrology. Upper Saddle River, Prentice Hall

Elhag M, Psilovikos A, Manakos I, Perakis K (2011) Application of the Sebs water balance modelin estimating daily evapotranspirationand evaporative fraction from remotesensing data over the Nile Delta. Water Resour Manag 25:2731-2742

Fujihara Y, OdaM, Horikawa N, Ogura C (2011) Hydrologic analysis of rainfed rice areas using a simple semi-distributed water balance model. Water Resour Manag 25:2061-2080

He B, Wang Y, Takase K, Mouri G, Razafindrabe BHN (2009) Estimating land use impacts on regional scale urbanwater balance and groundwater recharge. Water Resour Manag 23:1863-1873

Heafner H, Schumann AH (1992) Remote sensing applications in hydrology and water resources management. Department of Geography, University of Zurich, Zurich

Höllermann B, Giertz S, Diekkrüger B (2010) Benin 2025-balancing future water availabilityand demand using the WEAP 'Water Evaluationand Planning' system. Water Resour Manag 24:3591-3613

Jasrotia AS, Majhi A, Singh S (2009) Water balance approach for rainwater harvestingusing remote sensing and GIS techniques, Jammu Himalaya, India. Water Resour Manag 23:3035-3055

Manghi F, Mortazavi B, Crother C, Hamdi MR (2009) Estimating regional groundwater recharge usinga hydrological budget method. Water Resour Manag 23:2475-2489

Nhedzi E (2008) Assessment of a catchment water balance using GIS and remote sensing techniques: Mazowe, Zimbabwe, MSc thesis, ITC, the Netherlands

Rientjes THM (2007) Modeling in hydrology, Department of water resources, ITC, Enschede, the Netherlands

Senay GB, Budde M, Verdin JP, Melesse AM (2007) A coupled remote sensing and simplified surface energy balance approach to estimate actual evapotranspiration from irrigated fields. Sensors 2007(7):979-1000

Setegn SG, Chowdary VM, Mal BC, Yohannes F, Kono Y (2011) Water balance study and irrigation strategiesfor sustainable management of a tropicalEthiopian lake: a case study of lake Alemaya. Water Resour Manag 25:2081-2107

Smith DI, Stopp P (1978) The River basin: an introduction to the study of hydrology (Cambridge topics in geography), Cambridge University Press

Tang Q, Hu H, Oki T, Tian F (2007) Water balance within intensively cultivated alluvial plain in an arid environment. Water Resour Manag 21:1703-1715

Xu CY (1999) Estimation of parameters of a conceptual water balance model for ungauged catchments. Water Resour Manag 13:353-368

Xu CY, Singh VP (1998) A review on monthly water balance models for water resources investigations. Water Resour Manag 12:31-50 